\title{
Fish cytokines: current research and applications
}

\author{
Masahiro Sakai ${ }^{1} \cdot$ Jun-ichi Hikima ${ }^{1} \cdot$ Tomoya Kono $^{1}$
}

Received: 28 August 2020 / Accepted: 20 October 2020 / Published online: 3 December 2020

(c) The Author(s) 2020

\begin{abstract}
Cytokines are low molecular weight glycoproteins involved in the regulation of the immune system, and more than 100 cytokines have hitherto been identified in humans. Cytokines similar to those found in humans have also been found in fish. The innate immune response of fish can be examined by using cytokines as markers. We developed a multiplex reverse transcription-polymerase chain reaction assay to analyze the expression of various cytokine genes. Using this assay, we were able to investigate the fish immune response when it had been activated by immunostimulants. The involvement of inflammatory cytokines, such as interleukin- $1 \beta$, in the immune system of fish was revealed following administration of an immunostimulant.
\end{abstract}

Keywords Cytokine $\cdot$ Immunostimulant $\cdot$ Multiplex reverse transcription-polymerase chain reaction assay $\cdot$ Fish

\section{Introduction}

A major concern in aquaculture is the occurrence of fish diseases, which have hitherto mainly been controlled by administering antibacterial agents. However, because of the emergence of drug-resistant bacteria and problems associated with food hygiene as a consequence, it is preferable to avoid treating fish diseases with antibacterial drugs (Sakai 1999).

The immune system of higher vertebrates comprises innate and acquired immunity. Acquired immunity involves the recognition of foreign antigens via antigen receptors on $\mathrm{T}$ - and B-lymphocyte membranes. These antigen receptors are activated via antigen stimulation and have high affinity to a specific antigen. The establishment of acquired immunity usually requires several days, and a rapid immune response to, for example, microbial infection is not always initiated

Published with support by the Japan Society for the Promotion of Science (JSPS) KAKENHI Grant no. JP19HP2002.

Masahiro Sakai

m.sakai@cc.miyazaki-u.ac.jp

Jun-ichi Hikima

jhikima@cc.miyazaki-u.ac.jp

Tomoya Kono

tkono@cc.miyazaki-u.ac.jp

1 Faculty of Agriculture, University of Miyazaki, 1-1

Gakuenkibanadai-nishi, Miyazaki 889-2192, Japan
(Nakanishi et al. 2018). On the other hand, an innate immune response is required at the early stages of infection and is mainly attained through the action of phagocytes and humoral factors (Nakanishi et al. 2018).

Innate immunity is conventionally regarded as more important than acquired immunity in preventing infectious diseases in fish. Cytokines are mainly secreted by cells of both the innate and acquired immune systems. These molecules effect small physiological changes via specific receptors present on target cell surfaces and are responsible for signal transmission between cells (Zou and Secombes 2016). Cytokines play an important role in the innate immune response of fish. In this review, recent research on cytokine genes is presented, with a specific focus on describing the molecules important to the innate immune responses of fish, and the immunostimulants that elicit them.

\section{Fish cytokines}

Cytokines are involved in various regulatory processes in the vertebrate immune system, and over 100 types have been discovered in humans. Recent genomic studies have confirmed that fish have almost all the same cytokines as mammals (Savan and Sakai 2006; Zou and Secombes 2016). In this review, we discuss the main cytokine molecules of fish. 


\section{Interleukin-1 family}

Interleukin (IL) 1 is a pro-inflammatory cytokine that plays an important role in innate immunity. In addition to IL-1, around 100 types of IL are presently known in humans. Recent genomic studies have identified IL-1 as the evolutionarily earliest cytokine in fish (Zou et al. 1999; Wang et al. 2009). In mammals, the genes coding for IL- $1 \alpha$ and IL- $1 \beta$ are found on the same chromosome and are adjacent to one another, whereas in fish, only the gene encoding for IL-1 $\beta$ has so far been identified. Using DNA vaccination, Kono et al. (2002), reported that IL-1 plays an important role in fish immunity by activating lymphocytes and phagocytic cells and increasing resistance to Aeromonas hydrophila infection. Recently, a newer type of $i l l b$ gene was discovered in Japanese medaka Oryzias latipes. This gene is $76.0 \%$ homologous to the previously identified $i l l b$ gene, and is present on different chromosomes (Morimoto et al., personal communication). Furthermore, this gene has been confirmed to have pro-inflammatory actions.

\section{IL-2 family}

In the IL-2 family, IL-2, IL-4, IL-7, IL-9, IL-15, and IL-21 are found in humans (Lin and Leonard 2018). IL-2, IL4/13A, IL-4/13B, IL-7, IL-15, and IL-21 have been reported in fish (Zou and Secombes 2016). As in mammals, the genes of IL-2 and IL-21 in fish are found in tandem (Bird et al. 2005). Two IL-4/13 genes in fish, $i l 4 / 13 a$ and $i l 4 / 13 b$, have been found to be counterparts of mammalian IL-4 and IL-13, and are thought to have arisen through genome duplication. Moreover, the presence of IL-15 was revealed for the first time in Japanese pufferfish Takifugu rubripes, and another $i l 15$ ortholog similar in structure to $i l 15$ has been confirmed in Japanese pufferfish and zebrafish Danio rerio (Gunimaladevi et al. 2007).

\section{IL-6 family}

The molecules identified in humans which belong to the IL-6 cytokine family are IL-6, IL-11, leukemia inhibitory factor (LIF), oncostatin M (OSM), and ciliary neurotrophic factor (CNTF). The IL-6 sub-family cytokines are major players in hematopoiesis, and have pro- and anti-inflammatory properties. IL-6, IL-11 and CNTF-like occur in fish, and M17 has been identified as a fish-specific molecule that could possibly be an ancestral molecule to LIF and OSM (Hanington and Belosevic 2007). Although the functions of these molecules have not been clarified, recombinant IL-6 has been reported to promote phagocyte proliferation in rainbow trout (Costa et al. 2011). The rIL-6-induced transient expression (up to $4 \mathrm{~h}$ post-stimulation) of SOCS1-3 and interferon (IFN) regulatory factor (IRF)-1, and more sustained upregulation of antimicrobial peptide (AMP) gene expression at a similar level, were found in primary (head kidney derived) macrophage cultures (Costa et al. 2011).

\section{IL-10 family}

IL-10, IL-19, IL-20, IL-22, IL-24, IL-26, and IFN- $\gamma$ are cytokines of the IL-10 family. In general, fish IL-10, similarly to mammalian orthologs, acts as a suppressor and exerts a conserved role in dampening inflammatory responses. The functions of IL-10 have been characterized in goldfish and carp (Piazzon et al. 2015). In fish, illo and $i l 19 / 20$ genes are present in tandem on the same chromosome and code for IL-22, IL-24, and IFN- $\gamma$ (Savan and Sakai 2006). We discovered that a newly identified IFN- $\gamma$ gene (ifngrel) exists next to the ifng gene (Igawa et al. 2006). IFN- $\gamma$ rel is thought to be involved in immune defense against bacterial infection. Elevated expression of the ifngrel gene in the carp, rohu Labeo rohita, has been reported following infection of the fish with A. hydrophila, Edwardsiella tarda, or Shigella flexneri (Swain et al. 2015).

\section{IL-17 family}

Genes of six members of the IL-17 family, IL-17A, IL-17B, IL-17C, IL-17D, IL-17E, and IL-17F, exist in humans. IL17A/F1, IL-17A/F2, IL-17A/F3, IL-17C, IL-17D, and a fish-specific IL-17 N, have been reported in fish (Korenaga et al. 2010). We examined the function of Japanese pufferfish IL-17A/F1 using its recombinant (r) protein, and found that it enhanced the expression of tumor necrosis factor $-\alpha$, (tnfa), illb, and il6 and activated phagocytes (Kono et al. 2011; Takahashi et al. 2020). In yellow croaker, IL-17A/ F1 has a higher ability to activate the transcriptional activity of NF- $\kappa B$ than IL-17A/F2 and IL-17A/F3 (Ding et al. 2016). In rainbow trout, rIL-17A/F2 is able to induce IL-6, chemokine CXCL- 8 and antimicrobial peptide $\beta$-defensin expression in splenocytes (Monte et al. 2013). Grass carp rIL-17A/F1 also induces several pro-inflammatory cytokines including tnfa, illb, il6 and the chemokine $c x c l 8$ in head kidney leukocytes (Du et al. 2015). Furthermore, the gene expression of digestive enzymes and antibacterial substances is suppressed when the $i l 17 a / f 1$ gene is knocked out by the clustered regularly interspaced short palindromic repeats (CRISPR)/CRISPR-associated protein (Cas) 9 system in Japanese medaka $O$. latipes (Okamura et al. 2020), suggesting that medaka IL-17A/F1 may have a role in maintaining healthy intestines by modulating the gut microbiome via transcriptional control of the affected genes. 


\section{Chemokine family}

Chemokines are produced in large quantities in areas of inflammation and induce the migration of leukocytes from blood vessels to inflamed tissues. To date, more than 50 chemokines have been identified in humans. Chemokines have four highly conserved cysteine residues and are classified into four subfamilies, namely $\mathrm{CXC}, \mathrm{CC}, \mathrm{CX} 3 \mathrm{C}$, and $\mathrm{XC}$, according to the motif formed by the two $\mathrm{N}$-terminal cysteine residues. Many chemokines have also been identified in fish. More than 100 types of zebrafish chemokines have been reported, although none that belong to the CX3C subfamily (Nomiyama et al. 2008). Several CXC chemokines, including CXCL8_L1 (IL-8), CXCL11_L1 ( $\gamma$ IFN-inducible protein), CXCL_F4 and CXCL_F5 were found to increase in rainbow trout cell lines (i.e., RTG-2 and RTS-11 cells) after rIL-1 $\beta$ stimulation (Chen et al. 2013).

\section{Interferon family}

Interferons are types of cytokines produced by animal cells in response to the invasion of viruses, heterologous RNA, and certain sugars. Cells infected with viruses are known to exhibit an interference phenomenon that blocks infection by other viruses. Human IFNs include type I IFNs (13 types of IFN- $\alpha$, IFN- $\beta$, IFN- $\omega$, IFN- $\varepsilon$, and IFN- $\kappa$ ), type II IFN (IFN- $\gamma$ ), and type III IFNs (IFN- $\lambda 1$, IFN- $\lambda 2$, and IFN- $\lambda 3$ ). In fish, type I IFNs (homologs to the human IFN- $\alpha$ and IFN- $\beta$ ) exhibit antiviral activity, and type II IFN (IFN- $\gamma$ ) have also been reported to exhibit bactericidal activity against intracellular parasitic bacteria (Zou and Secombes 2016). A type I IFN in fish has been shown to have antiviral activity, but the gene encoding it has introns and exons, unlike mammalian genes coding for IFN (Zou and Secombes 2016).

\section{TNF family}

The TNF family includes proteins with the following motifs: (LV)-x-(LIVH)-x3-G-(LIVMF)-Y-(LIYMHY)2X2-(QEKHL)-(LIVMGT)-X-(LIVMFY). More than 20 TNF molecules have been reported in humans, including TNF- $\alpha$, lymphotoxin (LT)- $\alpha$ cytokines involved in apoptosis, the Fas ligand, the TNF-related apoptosis-inducing ligand (TRAIL), the receptor activator of nuclear factor- $\kappa$ B (RANK) ligand,the TNF receptor superfamily member 4 (OX40) ligand, and proliferation-inducing ligand 20 (TNF ligand superfamily member 13; APRIL 20). At least ten TNF genes have been identified in pufferfish (Biswas et al. 2015). TNF- $\alpha$ is the most immunologically important molecule in the TNF family. In humans, three genes, tnfa, tnfb (also called $l t a$ ), and $l t b$ exist in tandem. In fish, two genes, tnfa and tnfn are duplicated in tandem on the chromosome (Savan et al. 2005). In addition, unlike mammals, fish have another tnfa on another chromosome (Kinoshita et al. 2014). It has been suggested that members of the fish TNF- $\alpha$ family are involved in the regulation of leukocyte homing, proliferation and migration. Constitutive expression of TNF- $\alpha$ was detected in the trout thymus, which suggests that it could play a role in promoting thymocyte growth (Hino et al. 2006). Members of the TNF- $\alpha$ family in fish exert pro-apoptotic activity, as do their mammalian homologues. High doses ( $>400 \mathrm{ng} / \mathrm{mL}$ ) of Chinese perch TNF- $\alpha$ induced apoptosis in human Hela cells (Xiao et al. 2007). In tilapia, TNF- $\alpha$ has been shown to upregulate granzyme expression in non-specific cytotoxic cells and to protect these cells from activation-induced cell death (Praveen et al. 2006).

\section{Other cytokines}

Other important cytokines in fish include the IL-12 subfamily molecules, IL-18, transforming growth factor (TGF)- $\beta$, and macrophage colony-stimulating factor (M-CSF) (Zou and Secombes 2016). The function of fish IL-12 has been studied in two different paralogues of the p40 chain heterodimerized with a common $\mathrm{p} 35$. In grouper, rIL-12 increased the concanavalin $\mathrm{A}(\mathrm{ConA})$-induced proliferation of peripheral blood lymphocytes and tnfa expression (Tsai et al. 2014). In amberjack Seriola dumerili, rIL-12-mixed Nocardia seriolae-FKC vaccine induced cell-mediated immunity and production of type 1 helper (Th1) cells with antigen memory against $N$. seriolae infection (Matsumoto et al. 2017). IL-18, as well as IL-1 $\beta$, is released after cleavage by caspase- 1 following stimulation of inflammasome with pathogen-associated molecular patterns or damageassociated molecular patterns. Unlike IL- $1 \beta$, which is transiently induced by inflammatory stimuli, IL-18 is constitutively expressed in tissues of the innate and adaptive immune defense systems in fish (Zou et al. 2004). Most studies on TGF- $\beta$ in fish have focused on its function, in combination with other cytokines, as a driver of Th17 differentiation (e.g., IL-6), but it is also a key immunosuppressive cytokine secreted by regulatory $\mathrm{T}$ cells (Haddad et al. 2008; Wei et al. 2015). Fish M-CSF was first identified from goldfish (Barreda et al. 2005), and was shown to induce the differentiation of monocytes into macrophages and the proliferation of monocyte-like cells with a mononuclear phagocyte function (Grayfer et al. 2009).

\section{Immune function enhanced by immunostimulants}

Many immunostimulants have been developed for use in aquaculture, the major ones of which are shown in Table 1 (Sakai 1999). Immunostimulants are generally considered to prevent disease by increasing the innate immune response; 
Table 1 Major immunostimulants influencing fish immune response

\begin{tabular}{|c|c|}
\hline Immunostimulants & References \\
\hline \multicolumn{2}{|l|}{ Synthetic chemicals } \\
\hline Levamisole & Kajita et al. 1990 \\
\hline FK-565 & Kitao and Yoshida 1986 \\
\hline MDP & Kodama et al. 1993 \\
\hline Imiquimod & Kitao et al. 2009 \\
\hline \multicolumn{2}{|l|}{ Biological substances } \\
\hline \multicolumn{2}{|l|}{ Bacterial derivatives } \\
\hline FCA & Olivier et al. 1985 \\
\hline Peptidoglucan & Itami et al. 1996 \\
\hline EF203 & Yoshida et al. 1993 \\
\hline LPS & Salati et al. 1987 \\
\hline Yeast glucan & Dalmo and Bogward 2008 \\
\hline \multicolumn{2}{|l|}{ Polysaccharides } \\
\hline Chitin & Sakai et al. 1992 \\
\hline Chitosan & Siwicki et al. 1994 \\
\hline Lentinan & Yano et al. 1989 \\
\hline Schizophyllan & Itami et al. 1994 \\
\hline Oligosaccharide & Yoshida et al. 1995 \\
\hline \multicolumn{2}{|l|}{ Animal extracts } \\
\hline Ete (tunicate) & Davis and Hayasaka 1984 \\
\hline Hde (abalone) & Sakai et al. 1991 \\
\hline Firefly squid & Siwicki et al. 1996 \\
\hline \multicolumn{2}{|l|}{ Plant extracts } \\
\hline Quillaja saponin & Ninomiya et al. 1995 \\
\hline Hops & Galina et al. 2009 \\
\hline \multicolumn{2}{|c|}{ Vaccines (inducing natural immune responses) } \\
\hline Vibrio & Sakai et al. 1995a, b \\
\hline Aquabirunavirus & Yamashita et al. 2009 \\
\hline \multicolumn{2}{|l|}{ Nutritional factors } \\
\hline Vitamin $\mathrm{C}$ & Pohlenz and Gatlin 2014 \\
\hline Vitamin E & Pohlenz and Gatlin 2014 \\
\hline \multicolumn{2}{|c|}{ Hormones, cytokines and others } \\
\hline Lactoferrin & Sakai et al. 1993 \\
\hline Lysozyme & Siwicki et al. 1998 \\
\hline Growth hormone & Sakai et al. 1996 \\
\hline Prolactin & Sakai et al. 1996 \\
\hline \multicolumn{2}{|c|}{ Cytokines (recombinant protein) } \\
\hline Interleukin- $1 \beta$ & Kono et al. 2002 \\
\hline Chemokine & Kono et al. 2003 \\
\hline Type-I interferon & Robertsen et al. 2003 \\
\hline Interferon- $\gamma$ & Jung et al. 2012 \\
\hline \multicolumn{2}{|l|}{ Nucleic acid } \\
\hline Nucleotides & Sakai et al. 2001 \\
\hline CpG motif of DNA & Tassakka and Sakai 2004 \\
\hline
\end{tabular}

MDP Muramyl dipeptide, FCA Freund's complete adjuvant, LPS lipopolysaccharide we describe here the immune mechanisms that they activate in fish.

\section{Activation of phagocytes}

Phagocytic cells are functionally activated by the administration of immunostimulants. The functions of phagocytic cells can be classified as migratory, phagocytic, and bactericidal, with phagocytosis the one most intensively investigated in immunostimulation research. Generally, the phagocytosis rate and phagocytic index of the renal and intraperitoneal phagocytes of fish treated with immunostimulants, e.g., levamisole (Kajita et al. 1990), and lactoferrin (Sakai et al. 1993), significantly increases. Furthermore, the phagocytosis rate and phagocytic index increased significantly after phagocytes had been cultured in vitro in a medium containing an immunostimulant (Sakai et al. 1995a, b).

The sterilizing pathways of phagocytic cells can be broadly divided into two types: systems that depend mainly on oxygen and those that do not. Oxygen-dependent systems basically comprise oxygen compounds (e.g., $\mathrm{O}_{2}$ and $\mathrm{H}_{2} \mathrm{O}_{2}$ ) and nitrogen compounds (e.g., $\mathrm{NO}, \mathrm{NO}_{2}, \mathrm{~N}_{2} \mathrm{O}_{3}$, and $\mathrm{NO}_{2}^{+}$). Bactericidal substances, such as lysozyme and defensin, are important oxygen-independent systems. The administration of chitin, lactoferrin, or levamisole as immunostimulants enhanced the bactericidal action of oxygen compounds and oxygenated compounds (superoxides) produced by phagocytes (Kajita et al. 1990; Sakai 1999; Sakai et al. 1992). The migration ability of phagocytic cells was reported to significantly increase in channel catfish fed with yeast glucansupplemented feed (Duncan and Klesius 1996).

\section{Activation of lymphocytes}

Lymphocytes have also been reported to be activated by the administration of immunostimulants. A lymphocyte mitogenic response was promoted in rainbow trout (Oncorhynchus mykiss) leukocytes cultured in a culture medium [with ConA and lipopolysaccharide (LPS)] containing firefly squid (Watasenia scintillans) extract in vitro; the production of macrophage-activating factor increased significantly (Siwicki et al. 1996). Similar results have been obtained with a growth hormone and glycyrrhizin (Jang et al. 1995; Sakai et al. 1996).

\section{Enhancement of complement activation}

The complement system is a series of enzyme systems that can destroy foreign substances either alone or in coordination with antibodies. The activation of complement systems can enhance the phagocytic ability of phagocytes, and immunostimulants can increase this activation. Engstad et al. (1992) reported an increase in a complement factor 
in Atlantic salmon (Salmo salar) injected with yeast glucan. Similar results have been reported in channel catfish (Ictalurus punctatus) (Li and Lovell 1985) and Atlantic salmon (Hardie et al. 1991) treated with high doses of vitamin C, and rainbow trout (Kajita et al. 1990) treated with levamisole.

\section{Activation of lysozyme}

Lysozyme is a heat-resistant antibacterial enzyme found in the serum and body surface mucus of fish. Glucans are generally known to increase lysozyme activity (Engstad et al. 1992). However, lysozyme activity did not increase in fish in response to the administration of chitin (Sakai et al. 1992) or lactoferrin (Sakai et al. 1995a, b).

Fish have two types of lysozyme genes: chicken-type (C-type) and goose-type (G-type) (Callewaert and Michiels 2010; Hikima et al. 2002). Lytic activity of fish lysozyme has been detected in skin mucus, serum, the kidneys (including head and trunk kidneys), liver, gills, and eggs (Saurabh and Sahoo 2008; Yano 1995). The expression of the lysozyme gene in these tissues was shown by Callewaert and Michiels (2010) and Hikima et al. (2002). The messenger RNA levels of C-type and G-type lysozymes are upregulated in many fish species following challenge with immunostimulants and pathogenic microbes (Hikima et al. 1997; Jiménez-Cantizano et al. 2008; Ye et al. 2010). In turbot Scophthalmus maximus, two G-type lysozyme genes have been identified, one of which showed significant upregulation in the intestine following infection with Vibrio anguillarum and Streptococcus iniae (Gao et al. 2016). Furthermore, recombinant fish C-type lysozymes possess bacteriolytic and/or bactericidal activities against several Gram-positive and Gram-negative bacterial pathogens (Minagawa et al. 2001; Hikima et al. 2001; Ye et al. 2010; Gao et al. 2012).

\section{Disease prevention with immunostimulants}

Diseases that can be prevented by the use of immunostimulants include streptococcosis, vibriosis, and furunculosis, all of which are caused by extracellular bacteria. Few cases of immunostimulants being effective against viral diseases or intracellular bacteria, such as bacteria responsible for bacterial kidney disease, have been documented. In most cases, activated phagocytes are effective against extracellular bacteria. The activation of IL- $1 \beta$ and TNF- $\alpha$ is indispensable for this because their activation effects several innate immune responses including phagocytosis (Sakai 1999). The activation of type-I IFN is most effective against viral infections. In Japanese flounder Paralichthys olivaceus, rIFN- $\gamma$ is effective in reinforcing immune responses and preventing edwardsiellosis (Jung et al. 2012).

\section{Expression of cytokine genes in immunostimulant-treated or bacteria-infected fish assayed by multiplex reverse transcription- polymerase chain reaction assay}

\section{Multiplex reverse transcription-polymerase chain reaction assay}

The multiplex reverse transcription-polymerase chain reaction (RT-PCR) assay is designed to simultaneously amplify multiple genes during one test in one reaction tube (Bonetta 2006). We performed multiplex RT-PCR assay using chimeric primers for each gene designed by GenomeLab GeXP (Beckman Coulter), and quantified each gene. As the level of gene expression is investigated by amplifying and analyzing multiple genes in one tube with this method, both the duration and cost of analysis could be greatly reduced, enabling comprehensive examination of the expression levels of various genes.

In this multiplex RT-PCR reaction, each chimeric primer (i.e., a primer composed of both a gene-specific and universal sequences) was constructed so that the PCR products had different sizes. The PCR products of each gene were synthesized by using these chimeric primers so that universal sequences were added to both the $5^{\prime}$ and $3^{\prime}$ ends during the reverse transcription reaction and several PCR cycles. Thereafter, a universal primer labeled with a fluorescent dye was used during synthesis, so that a fluorescent PCR product was produced. The PCR products were fractionated based on size via capillary gel electrophoresis, and the gene expression level was calculated by detecting the fluorescence intensity of each gene.

\section{Development of a multiplex RT-PCR assay to quantify fish cytokine genes}

We successfully developed a multiplex RT-PCR assay for the comprehensive quantification of fish cytokine gene expression. We clarified the existence of, and cloned, various cytokine genes from the Japanese pufferfish $T$. rubripes (Table 2) (Kono et al. 2013).

\section{Expression of cytokine genes in immunostimulant-treated or bacteria-infected fish}

The effectiveness of fish immunostimulants was examined using the above-mentioned cytokine-multiplex RT-PCR assay. Table 3 shows the changes over time in the expression of various cytokine genes, with LPS causing a strong 
Table 2 Cytokine gene expression examined in puffer fish by using a cytokine-multiplex reverse transcription-polymerase chain reaction assay

\begin{tabular}{|c|c|c|c|c|c|c|c|}
\hline Cytokines & Abbreviation (gene) & Inflammation & $\begin{array}{l}\text { Anti- } \\
\text { inflamma- } \\
\text { tion }\end{array}$ & $\begin{array}{l}\text { T-cell prolifera- } \\
\text { tion/differentiation }\end{array}$ & $\begin{array}{l}\text { B-cell activation/ } \\
\text { differentiation }\end{array}$ & $\begin{array}{l}\text { NK cell } \\
\text { stimulation }\end{array}$ & $\begin{array}{l}\text { Anti- } \\
\text { viral } \\
\text { activity }\end{array}$ \\
\hline Interleukin- $1 \beta$ & IL-1 $\beta(i l 1 b)$ & 0 & & & & & \\
\hline Interleukin-2 & IL-2 (il2) & & & 0 & & & \\
\hline Interleukin-4/13A & IL-4/13A $(i l 4 / 13 a)$ & & 0 & & 0 & & \\
\hline Interleukin-4/13B & IL-4/13B (il4/13b) & & 0 & & $\bullet$ & & \\
\hline Interleukin-6 & IL-6 (il6) & ○ & & & $\bullet$ & & \\
\hline Interleukin-7 & IL-7 (il7) & & & & 0 & & \\
\hline Interleukin-10 & IL-10 (il10) & & 0 & & & & \\
\hline Interleukin-15 & IL-15 (il15) & & & 0 & & & \\
\hline Interleukin-17A/F3 & IL-17A/F3 (il17a/f3) & 0 & & & & & \\
\hline Interleukin-18 & IL-18 (il18) & ○ & & & & & \\
\hline Interleukin-12p35 & IL-12p35 (il12p35) & & & & & $\bullet$ & \\
\hline Interleukin-12p40 & IL-12p40 (il12p40) & & & & & $\bullet$ & \\
\hline Interleukin-21 & IL-21 (il21) & & & 0 & & & \\
\hline Interferon- $\gamma$ & IFN- $\gamma($ ifng $)$ & & & & & & $\bullet$ \\
\hline Type I-interferon 1 & Type-I IFN (ifnl) & & & & & & 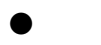 \\
\hline TNF- $\alpha$ & $\mathrm{TNF}-\alpha(t n f a)$ & 0 & & & & & \\
\hline
\end{tabular}

NK Natural killer

Table 3 Cytokine responses in pufferfish anterior kidney cells treated with LPS or polyinosinic-polycytidylic acid [poly $(I: C)]$

\begin{tabular}{|c|c|c|c|c|c|c|}
\hline \multirow[t]{2}{*}{ Cytokines } & \multicolumn{3}{|l|}{ LPS } & \multicolumn{3}{|c|}{ Poly(I:C) } \\
\hline & $1 \mathrm{~h}$ & $12 \mathrm{~h}$ & $24 \mathrm{~h}$ & $1 \mathrm{~h}$ & $12 \mathrm{~h}$ & $24 \mathrm{~h}$ \\
\hline IL-1 $\beta$ & $\uparrow \uparrow$ & $\uparrow \uparrow \uparrow$ & $\uparrow \uparrow$ & $\uparrow \uparrow$ & $\uparrow \uparrow$ & $\uparrow$ \\
\hline IL-2 & $\rightarrow$ & $\rightarrow$ & $\uparrow$ & $\rightarrow$ & $\rightarrow$ & $\uparrow$ \\
\hline IL-4/13A & $\rightarrow$ & $\downarrow$ & $\downarrow$ & $\downarrow$ & $\rightarrow$ & $\downarrow$ \\
\hline IL-4/13B & $\rightarrow$ & $\rightarrow$ & $\rightarrow$ & $\rightarrow$ & $\rightarrow$ & $\rightarrow$ \\
\hline IL-6 & $\uparrow \uparrow \uparrow$ & $\uparrow \uparrow \uparrow$ & $\uparrow \uparrow$ & $\uparrow \uparrow \uparrow$ & $\uparrow \uparrow$ & $\uparrow \uparrow$ \\
\hline IL-7 & $\rightarrow$ & $\downarrow$ & $\rightarrow$ & $\rightarrow$ & $\rightarrow$ & $\rightarrow$ \\
\hline IL-10 & $\uparrow$ & $\rightarrow$ & $\uparrow \uparrow$ & $\rightarrow$ & $\rightarrow$ & $\rightarrow$ \\
\hline IL-12p35 & $\uparrow \uparrow$ & $\uparrow$ & $\rightarrow$ & $\uparrow \uparrow$ & $\uparrow \uparrow$ & $\rightarrow$ \\
\hline IL-12p40 & $\uparrow$ & $\uparrow$ & $\uparrow$ & $\uparrow \uparrow$ & $\uparrow \uparrow$ & $\uparrow$ \\
\hline IL-15 & $\rightarrow$ & $\rightarrow$ & $\rightarrow$ & $\rightarrow$ & $\rightarrow$ & $\rightarrow$ \\
\hline IL-17A/F3 & $\uparrow \uparrow$ & $\rightarrow$ & $\downarrow$ & $\rightarrow$ & $\rightarrow$ & $\rightarrow$ \\
\hline IL-18 & $\rightarrow$ & $\rightarrow$ & $\rightarrow$ & $\rightarrow$ & $\rightarrow$ & $\rightarrow$ \\
\hline IL-21 & $\rightarrow$ & $\rightarrow$ & $\rightarrow$ & $\downarrow$ & $\rightarrow$ & $\uparrow$ \\
\hline IFN- $\gamma$ & $\uparrow \uparrow$ & $\uparrow \uparrow$ & $\rightarrow$ & $\uparrow \uparrow$ & $\uparrow \uparrow$ & $\uparrow \uparrow$ \\
\hline Type-I IFN & ND & ND & ND & $\uparrow$ & $\uparrow \uparrow \uparrow$ & $\uparrow$ \\
\hline TNF- $\alpha$ & $\uparrow$ & $\uparrow$ & $\uparrow$ & $\uparrow$ & $\uparrow \uparrow \uparrow$ & $\downarrow$ \\
\hline
\end{tabular}

$N D$ Not determined; for other abbreviations, see Tables 1 and 2 inflammatory reaction and polyinosinic-polycytidylic acid [poly(I:C)] exhibiting antiviral activity. In pufferfish treated with LPS, the expression of IL- $1 \beta$, TNF- $\alpha$, IL-6, and IL$17 \mathrm{~A}$ genes as pro-inflammatory cytokines was confirmed to increase 4-8 h after administration. Increased expression of IL-4/13A and IL-12p35 genes was also observed. At $24 \mathrm{~h}$ after LPS administration, the expression of the IL-10 gene increased, whereas that of IL- $1 \beta$ and TNF- $\alpha$ genes decreased to pre-stimulation levels. An increase in the expression of type-I IFN genes was not confirmed. In cells treated with poly(I:C), an increased expression of IL- 6 , TNF- $\alpha$, and other genes was observed, similar to that for LPS administration, but with a marked increase in type-I IFN gene expression. Thus, LPS and poly(I:C) activated different cytokines. 


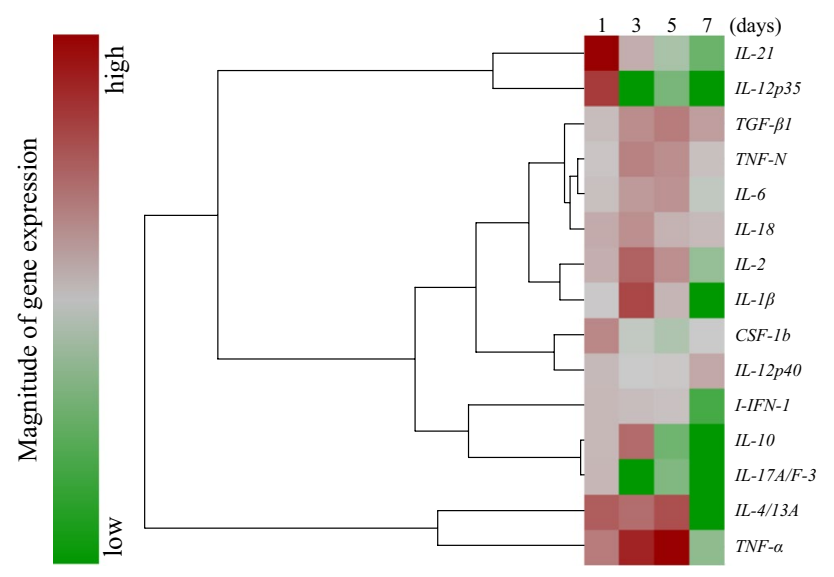

Fig. 1 Multiplex reverse transcription-polymerase chain reaction assay for messenger RNA expression of cytokines in fugu Takifugu rubripes exposed to Edwardsiella tarda (OA-3). The heat map depicts the relative expression level in the spleen compared to that in the uninfected control. The color scale illustrates the relative expression level of the cytokines: high relative expression (red), low relative expression (green). IL Interleukin, $T G F$ transforming growth factor, $T N F-N$ tumor necrosis factor-N, CSF colony-stimulating factor, IIFN-1 type 1 interferon

The cytokine responses in pufferfish infected with $E$. tarda are shown in Fig. 1. Increased IL-21 expression was observed on the first day after infection, and TNF- $\alpha$ expression levels were increased on the fifth day. In contrast, the expression of IL-1 $\beta$, IL-10, IL-17A, type-I IFN, and IL-4/13A genes decreased 7 days after infection.

\section{Conclusion}

In this review, we have described the roles of cytokines and their use as indices of innate immunity in fish, and introduced methods that can be used to detect them (e.g., the multiplex RT-PCR assay). However, research to elucidate the functions of cytokines in fish has only recently begun, and further work is necessary for the selection of, for example, appropriate immunostimulants and vaccine adjuvants for the prevention of infections in farmed fish.

Acknowledgments We wish to express our sincere gratitude to Professor Emeritus Takashi Aoki, Tokyo University of Marine Science and Technology, for his kind guidance and encouragement throughout this research. This work was supported by a Grant-in-Aid for Scientific Research (A) (grant no. 17H01486) from the Japan Society for the Promotion of Science, Japan. We would like to thank Editage (www. editage.jp) for the English language editing of an earlier version of this manuscript.

Open Access This article is licensed under a Creative Commons Attribution 4.0 International License, which permits use, sharing, adaptation, distribution and reproduction in any medium or format, as long as you give appropriate credit to the original author(s) and the source, provide a link to the Creative Commons licence, and indicate if changes were made. The images or other third party material in this article are included in the article's Creative Commons licence, unless indicated otherwise in a credit line to the material. If material is not included in the article's Creative Commons licence and your intended use is not permitted by statutory regulation or exceeds the permitted use, you will need to obtain permission directly from the copyright holder. To view a copy of this licence, visit http://creativecommons.org/licenses/by/4.0/.

\section{References}

Barreda DR, Hanington PC, Stafford JL, Belosevic M (2005) A novel soluble form of the CSF-1 receptor inhibits proliferation of selfrenewing macrophages of goldfish (Carassius auratus L.). Dev Comp Immunol 29:879-894

Bird S, Zou J, Kono T, Sakai M, Dijkstra JM, Secombes C (2005) Characterization and expression analysis of interleukin 2 (IL2) and IL-21 homologues in the Japanese pufferfish, Fugu rubripes, following their discovery by synteny. Immunogenetics 56:909-923

Biswas G, Kinoshita S, Kono T, Hikima J, Sakai M (2015) Evolutionary evidence of tumor necrosis factor super family members in the Japanese pufferfish (Takifugu rubripes): comparative genomic identification and expression analysis. Mar Genomics 14:25-36

Bonetta L (2006) Gene expression: one size does not fit all. Nat Methods 3:401-408

Callewaert L, Michiels CW (2010) Lysozymes in the animal kingdom. J Biosci 35:127-160

Chen J, Xu Q, Wang T, Collet B, Corripio-Miyar Y, Bird S, Xie P, Nie P, Secombes CJ, Zou J (2013) Phylogenetic analysis of vertebrate CXC chemokines reveals novel lineage-specific groups in teleost fish. Dev Comp Immunol 41:137-152

Costa MM, Maehr T, Diaz-Rosales P, Secombes C, Wang T (2011) Bioactivity studies of rainbow trout (Oncorhynchus mykiss) interleukin-6: effects on macrophage growth and antimicrobial peptide gene expression. Mol Immunol 48:1903-1916

Dalmo RA, Bøgwald J (2008) B-glucans as conductors of immune symphonies. Fish Shellfish Immunol 25(4):384-396

Davis JF, Hayasaka SS (1984) The enhancement of resistance of the American eel, Anguilla rostrata Le Sueur, to a pathogenic bacterium Aeromonas hydrophila, by an extract of the tunicate Ecteinascidia turbinata. J Fish Dis 7:311-316

Ding Y, Ao J, Ai C, Chen X (2016) Molecular and functional identification of three interleukin-17A/F (IL-17A/F) homologues in large yellow croaker (Larimichthys crocea). Dev Comp Immunol $55: 221-232$

Du L, Feng S, Yin L, Wang X, Zhang A, Yang K, Zhou H (2015) Identification and functional characterization of grass carp IL-17A/F1: an evaluation of the immunoregulatory role of teleost IL-17A/F1. Dev Comp Immunol 51:202-211

Duncan PL, Klesius PH (1996) Dietary immunostimulants enhance nonspecific immune responses in channel catfish but not resistance to Edwardsiella ictaluri. J Aquat Anim Health 8:241-248

Engstad RE, Robertsen B, Frivold E (1992) Yeast glucan induces increase in activity of lysozyme and complement-mediated haemolytic activity in Atlantic salmon blood. Fish Shellfish Immunol 2:287-297

Galina J, Yin G, Ado L, Jeney Z (2009) The use of immunostimulating herbs in fish. An overview of research. Fish Physiol Biochem 35:669-676

Gao C, Fu Q, Zhou S, Song L, Ren Y, Dong X, Su B, Li C (2016) The mucosal expression signatures of g-type lysozyme in turbot (Scophthalmus maximus) following bacterial challenge. Fish Shellfish Immunol 54:612-619 
Gao FY, Qu L, Yu SG, Ye X, Tian YY, Zhang LL, Bai JJ, Lu MX (2012) Identification and expression analysis of three c-type lysozymes in Oreochromis aureus. Fish Shellfish Immunol 32:779-788

Grayfer L, Hanington PC, Belosevic M (2009) Macrophage colonystimulating factor (CSF-1) induces pro-inflammatory gene expression and enhances antimicrobial responses of goldfish (Carassius auratus L.) macrophages. Fish Shellfish Immunol 26:406-413

Gunimaladevi I, Savan R, Sato K, Yamaguchi R, Sakai M (2007) Characterization of an interleukin-15 like (IL-15L) gene from zebrafish (Danio rerio). Fish Shellfish Immunol 22:351-362

Haddad G, Hanington PC, Wilson EC, Grayfer L, Belosevic M (2008) Molecular and functional characterization of goldfish (Carassius auratus L.) transforming growth factor beta. Dev Comp Immunol 32:654-663

Hanington PC, Belosevic M (2007) Interleukin-6 family cytokine M17 induces differentiation and nitric oxide response of goldfish (Carassius auratus L.) macrophages. Dev Comp Immunol 31:817-829

Hardie LJ, Fletcher TC, Secombes CJ (1991) The effect of dietary vitamin $\mathrm{C}$ on the immune response of Atlantic salmon Salmo salar. Aquaculture 95:201-214

Hikima J, Hirono I, Aoki T (1997) Characterization and expression of c-type lysozyme cDNA from Japanese flounder (Paralichthys olivaceus). Mol Mar Biol Biotechnol 6:339-344

Hikima J, Hirono I, Aoki T (2002) The lysozyme gene in fish. In: Shimizu N, Aoki T, Hirono I, Takashima F (eds) Aquatic genomics-steps toward a great future. Springer, New York, pp 301-309

Hikima J, Minagawa S, Hirono I, Aoki T (2001) Molecular cloning, expression and evolution of the Japanese flounder goose-type lysozyme gene, and the lytic activity of its recombinant protein. Biochim Biophys Acta 1520:35-44

Hino K, Nakamura O, Yoshiura Y, Suetake H, Suzuki Y, Watanabe T (2006) TNF induces the growth of thymocytes in rainbow trout. Dev Comp Immunol 30:639-647

Lin JX, Leonard WJ (2018) The common cytokine receptor $\gamma$ chain family of cytokines. Cold Spring Harb Perspect Biol 10:a028449

Igawa D, Sakai M, Savan R (2006) An unexpected discovery of two interferon gamma-like genes along with interleukin (IL)-22 and IL-26 from teleost: IL-22 and IL-26 genes have been described for the first time outside mammals. Mol Immunol 43:999-1009

Itami T, Takahashi Y, Tsuchihira E, Igusa H, Kondo M (1994) Enhancement of disease resistance of kuruma prawn Penaeus japonicus and increase in phagocytic activity of prawn hemocytes after oral administration of $\beta$-1,3-glucan (schizophyllan). In: Chou LM (ed) The Third Asian Fisheries Forum. Asian Fisheries Society, Manila, pp 375-378

Itami T, Kondo M, Uozu M, Suganuma A, Abe T, Nakagawa A, Suzuki N, Takahashi Y (1996) Enhancement of resistance against Enterococcus seriolicida infection in yellowtail, Seriola quinqueradiata (Temminck and Schlegel), by oral administration of peptidoglucan derived from Bifidobacterium thermophilum. J Fish Dis 19:185-187

Jang SI, Marsden MJ, Kim YG, Choi MS, Secombes CJ (1995) The effect of glycyrrhizin on rainbow trout, Oncorhynchus mykiss Walbaum., leucocyte responses. J Fish Dis 18:307-315

Jiménez-Cantizano RM, Infante C, Martin-Antonio B, Ponce M, Hachero I, Navas JI, Manchado M (2008) Molecular characterization, phylogeny, and expression of c-type and g-type lysozymes in brill (Scophthalmus rhombus). Fish Shellfish Immunol 25:57-65

Jung CY, Hikima J, Ohtani M, Jang HB, del Castillo CS, Nho SW, Cha IS, Park SB, Aoki T, Jung TS (2012) Recombinant interferon- $\gamma$ activates immune responses against Edwardsiella tarda infection in the olive flounder, Paralichthys olivaceus. Fish Shellfish Immunol 33:197-203
Kajita T, Sakai M, Atsuta S, Kobayashi M (1990) The immunodulatory effects of levamisole on rainbow trout Oncorhynchus mykiss. Fish Pathol 25:93-98

Kinoshita S, Biswas G, Kono T, Hikima J, Sakai M (2014) Presence of two tumor necrosis factor (tnf)- $\alpha$ homologs on different chromosomes of zebrafish (Danio rerio) and medaka (Oryzias latipes). Mar Genomics 13:1-9

Kitao T, Yoshida T (1986) Effect of an immunopotentiator on Aeromonas salmonicida infection in rainbow trout (Salmo gairdneri). Vet Immunol Immunopathol 12:287-291

Kitao Y, Kono T, Korenaga H, Iizasa T, Nakamura K, Savan R, Sakai M (2009) Characterization and expression analysis of type I interferon in common carp Cyprinus carpio L. Mol Immunol 46:2548-2556

Kodama H, Hirota Y, Mukamoto N, Baba T, Azuma I (1993) Activation of rainbow trout (Oncorhynchus mykiss) phagocytes by muramyl dipeptide. Dev Comp Immunol 17:129-140

Kono T, Fujiki K, Nakao M, Yano T, Endo M, Sakai M (2002) The immune responses of common carp, Cyprinus carpio L., injected with carp interleukin-1 $\beta$ gene. J Interferon Cytokine Res 22:413-419

Kono T, Kusuda R, Kawahara E, Sakai M (2003) The analysis of immune responses of a novel CC-chemokine gene from Japanese flounder Paralichthys olivaceus. Vaccine 21:446-457

Kono T, Korenaga H, Sakai M (2011) Genomics of fish IL-17 ligand and receptors: a review. Fish Shellfish Immunol 31:635-643

Kono T, Takayama H, Nagamine R, Korenaga H, Sakai M (2013) Establishment of a multiplex RT-PCR assay for the rapid detection of fish cytokines. Vet Immunol Immunopathol 151:90-101

Korenaga H, Kono T, Sakai M (2010) Isolation of seven IL-17 family genes from the Japanese pufferfish Takifugu rubripes. Fish Shellfish Immunol 28:809-818

Li Y, Lovell RT (1985) Elevated levels of dietary ascorbic acid increase immune responses in channel catfish. J Nutr 115:123-131

Matsumoto M, Araki K, Hayashi K, Takeuchi Y, Shiozaki K, Suetake $\mathrm{H}$, Yamamoto A (2017) Adjuvant effect of recombinant interleukin-12 in the nocardiosis formalin-killed vaccine of the amberjack Seriola dumerili. Fish Shellfish Immunol 67:263-269

Minagawa S, Hikima J, Hirono I, Aoki T, Mori H (2001) Expression of Japanese flounder c-type lysozyme cDNA in insect cells. Dev Comp Immunol 25:439-445

Monte MM, Wang T, Holland JW, Zou J, Secombes CJ (2013) Cloning and characterization of rainbow trout interleukin-17A/F2 (IL$17 \mathrm{~A} / \mathrm{F} 2)$ and IL-17 receptor a: expression during infection and bioactivity of recombinant IL-17A/F2. Infect Immun 81:340-353

Nakanishi T, Hikima J, Yada T (2018) Osteichthyes: immune system in teleosts (Actinoptergii). In: Cooper ED (ed) Advances in comparative immunology. Springer, Cham, Switzerland, pp 687-749

Ninomiya M, Hatta H, Fujiki M, Kim M, Yamamoto T, Kusuda R (1995) Enhancement of chemotactic activity of yellowtail (Seriola quinqueradiata) leucocytes by oral administration of quillaja saponin. Fish Shellfish Immunol 5:325-328

Nomiyama H, Hieshima K, Osada N, Kato-Unoki Y, Otsuka-On K, Takegawa S, Izawa T, Toshizawa A, Kikuchi Y, Tamase S, Miura R, Kusuda J, Nakao M, Yoshie O (2008) Extensive expansion and diversification of the chemokine gene family in zebrafish: identification of a novel chemokine subfamily CX. BMC Genomics 9:222

Okamura Y, Morimoto N, Ikeda D, Mizusawa N, Watabe S, Miyanichi H, Saeki Y, Takeyama H, Aoki T, Kinoshita M, Kono T, Sakai M, Hikima J (2020) Interleukin-17A/F1 deficiency reduces antimicrobial gene expression and contributes to microbiome alterations in intestines of Japanese medaka (Oryzias latipes). Front Immunol 11:425

Olivier G, Evelyn TPT, Lallier R (1985) Immunity to Aeromonas salmonicida in coho salmon (Oncorhynchus kisutch) induced by modified Freund's complete adjuvant: its non-specific nature and 
the probable role of macrophages in the phenomenon. Dev Comp Immunol 9:419-432

Piazzon MC, Savelkoul HS, Pietretti D, Wiegertjes GF, Forlenza M (2015) Carp IL10 has anti-inflammatory activities on phagocytes, promotes proliferation of memory $\mathrm{T}$ cells, and regulates B cell differentiation and antibody secretion. J Immunol 194:187-199

Pohlenz C, Gatlin DM (2014) Interrelationships between fish nutrition and health. Aquaculture 431:111-117

Praveen K, Evans DL, Jaso-Friedmann L (2006) Constitutive expression of tumor necrosis factor-alpha in cytotoxic cells of teleosts and its role in regulation of cell-mediated cytotoxicity. Mol Immunol 43:279-291

Robertsen B, Bergan V, Røkenes T, Larsen R, Albuquerque A (2003) Atlantic salmon interferon genes: cloning, sequence analysis, expression, and biological activity. J Interferon Cytokine Res 23(10):601-612

Sakai M, Kamiya H, Atsuta S, Kobayashi M (1991) Immunodulatory effects on rainbow trout, Oncorhynchus mykiss, injected with the extract of abalone, Haliotis discus hannai. J Appl Ichthyol 7:54-59

Sakai M, Kamiya H, Ishii S, Atsuta S, Kobayashi M (1992) The immunostimulating effects of chitin in rainbow trout, Oncorhyncus mykiss. Dis Asian Aquacult 1:413-417

Sakai M, Otubo T, Atsuta S, Kobayashi M (1993) Enhancement of resistance to bacterial infection in rainbow trout, Oncorhynchus mykiss (Walbaum) by oral administration of bovine lactoferrin. $\mathrm{J}$ Fish Dis 16:239-247

Sakai M, Atsuta S, Kobayashi M (1995) Efficacies of combined vaccine for Vibrio anguillarum and Streptococcus sp. Fish Sci 61:359-360

Sakai M, Kobayashi M, Kawauchi H (1996) Mitogenic effects of growth hormone and prolactin on chum salmon Oncorhynchus keta leucocytes in vitro. Vet Immunol Immunopathol 53:185-189

Sakai M, Kobayashi M, Yoshida T (1995) Activation of rainbow trout, Oncorhynchus mykiss, phagocytic cells by administration of bovine lactoferrin. Comp Biochem Physiol 110:755-759

Sakai M (1999) Current research status of fish immunostimulants. Aquaculture 172:63-92

Sakai M, Taniguchi K, Mamoto K, Igawa H, Tabata M (2001) Immunostimulant effects of nucleotide isolated from yeast RNA on carp, Cyprinus carpio L. J Fish Dis 24:433-438

Salati F, Hamaguchi M, Kusuda R (1987) Immune response of red sea bream to Edwardsiella tarda antigens. Fish Pathol 22:93-98

Saurabh A, Sahoo PK (2008) Lysozyme: an important defence molecule of fish innate immune system. Aquac Res 39:223-239

Savan R, Kono T, Igawa D, Sakai M (2005) A novel tumor necrosis factor (TNF) gene present in tandem with the TNF- $\alpha$ gene on the same chromosome in teleosts. Immunogenetics 57:140-150

Savan R, Sakai M (2006) Genomics of fish cytokines. Comp Physiol Biochem (D) 1:89-101

Siwicki AK, Anderson DP, Rumsey GL (1994) Dietary intake of immunostimulants by rainbow trout affects non-specific immunity and protection against furunculosis. Vet Immunol Immunopathol 41:125-139

Siwicki AK, Miyazaki T, Komatsu I, Matsuzato T (1996) In vitro influence of heat extract from firefly squid Watasenia scintillans on the phagocyte and lymphocyte activities in rainbow trout Oncorhynchus mykiss. Fish Pathol 31:1-7

Siwicki AK, Morand M, Klein P, Kiczka W (1998) Treatment of infectious pancreatic necrosis virus (IPNV) disease using dimerized lysozyme (KLP-602). J Appl Ichthyol 14:229-232

Swain B, Basu M, Lenka SS, Das S, Jayasankar P, Samanta M (2015) Characterization and inductive expression analysis of interferon gamma-related gene in the Indian major carp, rohu (Labeo rohita). DNA Cell Biol 34:367-378

Takahashi Y, Okamura Y, Morimoto T, Mihara K, Maekawa S, Wang HC, Aoki T, Kono T, Sakai M, Hikima J (2020) Interleukin-17A/ F1 from Japanese pufferfish (Takifugu rubripes) stimulates the immune response in head kidney and intestinal cells. Fish Shellfish Immunol 103:143-149

Tassakka ACMAR, Sakai M (2004) Expression of immune-related genes in the common carp (Cyprinus carpio) after stimulation by CpG oligodeoxynucleotides. Aquaculture 242:1-12

Tsai JL, Priya TAJ, Hu KY, Yan HY, Shen ST, Song YL (2014) Grouper interleukin-12, linked by an ancient disulphide-bond architecture, exhibits cytokine and chemokine activities. Fish Shellfish Immunol 36:27-37

Wang T, Bird S, Koussounadis A, Holland JW, Carrington A, Zou J, Secombes CJ (2009) Identification of a novel IL-1 cytokine family member in teleost fish. J Immunol 183:962-974

Wei H, Yin L, Feng S, Wang X, Yang K, Zhang A, Zhou H (2015) Dual-parallel inhibition of IL-10 and TGF- $\beta 1$ controls LPSinduced inflammatory response via NF- $\mathrm{kB}$ signalling in grass carp monocytes/macrophages. Fish Shellfish Immunol 44:445-452

Xiao J, Zhou ZC, Chen C, Huo WL, Yin ZX, Weng SP, Chan SM, Yu XQ, He JG (2007) Tumor necrosis factor-alpha gene from mandarin fish, Siniperca chuatsi: molecular cloning, cytotoxicity analysis and expression profile. Mol Immunol 44:3615-3622

Yamashita H, Mori K, Nakai T (2009) Protection conferred against viral nervous necrosis by simultaneous inoculation of aquabirnavirus and inactivated betanodavirus in the sevenband grouper, Epinephelus septemfasciatus (Thunberg). J Fish Dis 32:201-210

Yano T (1995) The complement systems of fish. Fish Pathol 302:151-158

Yano T, Mangindaan REP, Matsuyama H (1989) Enhancement of the resistance of carp Cyprinus carpio to experimental Edwardsiella tarda infection by some $\beta$-1,3-glucans. Nippon Suisan Gakkaishi 55:1815-1819

Ye X, Zhang L, Tian Y, Tan A, Bai J, Li S (2010) Identification and expression analysis of the g-type and c-type lysozymes in grass carp Ctenopharyngodon idellus. Dev Comp Immunol 34:501-509

Yoshida T, Sakai M, Kitao T, Khlil MS, Araki S, Saitoh R, Ineno T, Inglis V (1993) Immunodulatory effects of the fermented products of chicken egg, EF203, on rainbow trout, Oncorhynchus mykiss. Aquaculture 109:207-214

Yoshida T, Kruger R, Inglis V (1995) Augmentation of non-specific protection in African catfish, Clarias gariepinus (Burchell), by the long-term oral administration of immunostimulants. J Fish Dis 18:195-198

Zou J, Grabowski PS, Cunningham C, Secombes CJ (1999) Molecular cloning of interleukin $1 \beta$ from rainbow trout Oncorhynchus mykiss reveals no evidence of an ice cut site. Cytokine 11:552-560

Zou J, Bird S, Truckle J, Bols N, Horne M, Secombes C (2004) Identification and expression analysis of an IL-18 homologue and its alternatively spliced form in rainbow trout (Oncorhynchus mykiss). Eur J Biochem 271:1913-1923

Zou J, Secombes CJ (2016) The function of fish cytokines. Biology $5: 23$

Publisher's Note Springer Nature remains neutral with regard to jurisdictional claims in published maps and institutional affiliations. 